\title{
POTENTIAL APPLICATIONS OF NANOMATERIALS IN WASTEWATER TREATMENT
}

\section{Zuzana SANNY ${ }^{1}$, Alexandra KUCMANOVÁ ${ }^{1}$, Kristína GERULOVÁ ${ }^{1}$, Lenka GABRIŠOVÁ ${ }^{1}$}

\author{
${ }^{1}$ SLOVAK UNIVERSITY OF TECHNOLOGY IN BRATISLAVA \\ FACULTY OF MATERIALS SCIENCE AND TECHNOLOGY IN TRNAVA \\ INSTITUTE OF INTEGRATED SAFETY \\ Ulica JÁNA BOTTU 2781/25, 91724 TRNAVA, SLOVAK REPUBLIC \\ e-mail: zuzana.sanny@stuba.sk, alexandra.kucmanova@stuba.sk, kristina.gerulova@ stuba.sk \\ Received 26 April 2021, Accepted 23 June 2021, Published 20 July 2021
}

\begin{abstract}
Over the last few decades, nanotechnologies have gained a great deal of attention, and various nanomaterials and techniques have been developed for water remediation. This study deals with the adsorption of Naphthol green B onto the magnetite nanoparticles synthetized by the coprecipitation method at the laboratory temperature. According to the obtained results, the sorption process is obvious only at the acidic condition when the $p H$ of solution decreases to $\mathrm{pH}$ level 3. According to nonlinear fit of experimental data, the sorption of the Naphthol green B onto magnetite nanoparticles is assumed as multilayer, while the Freundlich model fits better (96.158\%) than the Langmuir model does (55.941\%).
\end{abstract}

\section{Keywords}

Adsorption, magnetite, $\mathrm{Fe}_{3} \mathrm{O}_{4}$, dyes, naphthol green $\mathrm{B}$

\section{INTRODUCTION}

Residual dyes are the main contaminants present in wastewater from many industries, such as dyeing, cosmetics, food, hair dye, inks, packaging, paper and pulp, pharmaceuticals, plastics, printing, rubber, textiles and others that pollute water [1]. In the textile industry, dyeing is associated with a large amount of water, and thus produces a larger amount of coloured wastewater. In that industry, there is about 1-2 \% loss of dyes in wastewater during the production of dyes, and 1-10\% loss of dyes in wastewater during the use of dyes. Residual dyes in wastewater are common pollutants in water even in small quantities [2]. A dye concentration of only $1.0 \mathrm{mg}$ per litre adds colour to wastewater and is considered unfit for human consumption. It can cause several health problems [3]. Dye contamination poses a serious risk because conventional dyes usually exhibit a synthetic and complex chemical structure making them very stable and difficult to biodegrade $[4,5]$. Wastewater colour is one 
of the key water quality measures. The discharge of synthetic dyes into water bodies prevents light from entering the aquatic flora, thus preventing photosynthesis. Wastewater is discharged into agricultural fields, thereby reducing soil productivity, preventing root penetration, and damaging soil structure. Organic substances present in textile wastewater react with many disinfectants, especially chlorine, which can evaporate into the air and enter the human body by inhalation and absorption through the skin, causing allergic reactions [6].

\section{Dyes classification}

Dyes can be classified according to chemical structure, colours, applications and the number of particles in solution. Normally, dyes can be divided into natural (natural sources such as plants, animals, including hematoxylin, carmine and orcein) and synthetic dyes (organic, inorganic compounds). Synthetic dyes are gradually replacing natural dyes, especially in textile industries. In addition to the above categorization, dyes are very often classified according to chemical structure, including azo, anthraquinone, indigoid, nitroso, nitro and triarylmethane [7, 8]. Azo dyes are the most important group of synthetic dyes and represent the largest class of the dyes used. Many types of azo dyes are known, and there are several classification systems. Some classes include dispersing dyes. In another classification, azo dyes can be classified according to the number of azo groups. Most azo dyes contain only one azo group (monoazo), but some may contain two (diazo), four (tetrakisazo) or more classes. Azo compounds are widely used in many industries, such as textiles, cosmetics and paper [9].

Naphthol Green B (NGB) sometimes specifically referred to as Acid Green 1. NGB is a complex of iron $\left(3^{+}\right)$with 1-nitroso-2-naphthol-6-sulfonic acid [10]. Naphthol green-B is one of the highly soluble anionic dyes, which belongs to the azo dyes and is a derivative of naphthenic acid. This dye is mainly used by the textile industry to dye and print wool, nylon silk fabrics and leather. It has photo-redox properties, and can be involved in electropolymerization. However, iron does not appear to play a role in tissue staining [11]. Owing to its low cost and efficiency of electron transfer, NGB acts as a mediator in electro catalysis, especially for dopamine and uric acid, and can also be used in several spectrophotometric devices [2]. Naphthol green dye B is dangerous for humans. It may cause health problems such as increased heart rate, shock, and cyanosis [5].

\section{Dye removal methods}

Dyes are extremely toxic, carcinogenic and cause mutations in various species of aquatic animals. High costs are incurred for the routine removal of pollution, and health problems are eradicated by eliminating biological and dye-based pollution [12]. Methods used to remove the dye include physical methods, chemical methods, and biological methods [1]. Multiple technologies have been applied to remove dyes from various aqueous solutions, including coagulation [13], flocculation [14], electrocoagulation [15, 16], electrochemical decolorization, froth flotation, ion exchange, membrane filtration, reverse osmosis, microbial decolorization and degradation (it is inexpensive, eco-friendly, and produces less amount of sludge for degradation of azo dyes) [17]. However, these methods (except for microbial method) contain non-negligible flaws in real industrial applications since they are of high capital and operational costs. Considering the initial cost, flexibility and simplicity of design, ease of operation and insensitivity to toxic pollutants, adsorption technique has been approved to be more effective in water re-use. However, except for the high cost, secondary pollution along with the necessity of using post grafting with functional groups to modify the surface of these adsorbents is another primary drawback for large-scale industrial applications. This suggests the significance of searching other alternative absorbent which would remain low- 
cost and equally effective [18]. Over the last few decades, several literature reviews concerning the use of low-cost adsorbents for wastewater treatment have been published [19]. However, traditional adsorption processes, using for example bentonite, require centrifugation or selfprecipitation stages, therefore these methods fail to treat large flow rates and for large-scale applications. In sharp contrast, magnetic nanomaterials, such as $\mathrm{Fe}_{3} \mathrm{O}_{4}$, have drawn considerable attention and are extensively studied as removal adsorbents due to their magnetic properties and recycling capability [18]. Magnetic separation of adsorbents has proven its utility as a promising technique for wastewater treatment due to its advantages such as the lack of flocculants produced and the large quantity of effluent manipulated in a limited period of time, which recommend the magnetic materials as suitable candidates for dye sequestration with rapid separation and improved decontamination efficiency of water [20]. Adsorption studies have indicated the potential of iron oxide nanoparticles for environmental remediation as a result of their chemical stability, high surface areas and ease of magnetic recovery [21]. E.g. in [21] superparamagnetic magnetite nanoparticles synthesized by the chemical coprecipitation, the removal efficiency of indigo carmine dye was higher than in the commercial magnetite nanoparticles ( $87 \%$ removal efficiency in accordance to $33 \%$ in case of the commercial product).

\title{
MATERIALS AND METHODOLOGY OF EXPERIMENT
}

\section{Analytical methods}

The concentration of selected dyes in the solution was measured in a $1 \mathrm{~cm}$ cuvette using UV-VIS spectrophotometer (Genesis 8).

\begin{abstract}
Adsorbent
All chemicals were analytical grade and employed without any further purification. The synthesis of magnetite nanoparticles were performed according to the previously reported method [22] with certain modifications described below. The most important one was the change of temperature decreased from $80{ }^{\circ} \mathrm{C}$ to $20{ }^{\circ} \mathrm{C}$ because of saving the energy required for the particle's preparation. To synthetize one dose of $\mathrm{Fe}_{3} \mathrm{O}_{4}$ nanoparticles, $1.98 \mathrm{~g} \mathrm{FeCl}_{2} .4 \mathrm{H}_{2} \mathrm{O}$ and $5.4 \mathrm{~g} \mathrm{FeCl}_{3} .6 \mathrm{H}_{2} \mathrm{O}$ were dissolved in $200 \mathrm{~mL}$ distilled water in a three-neck flask vessel and vigorously stirred at the laboratory temperature $\left(20^{\circ} \mathrm{C}\right)$ under a nitrogen atmosphere (distilled water was previously deoxygenated by the nitrogen for 20-30 minutes). After the drop- wise addition of $20 \mathrm{~mL} \mathrm{NH} \mathrm{NH}_{4} \mathrm{OH}(25 \mathrm{wt} \%$ ) and continuous stirring for 30 minutes, the magnetite was precipitated in the solution. After standing the solution alone for one hour without stirring, the precipitate was washed three times with distilled water. The decantation process was accelerated using neodymium magnet. The Fe3O4 magnetic nanoparticles (MNP) were stored in the distilled water for further use in a closed glass bottle, while the concentration was determined gravimetrically. Nanoparticles prepared by this procedure had $57 \%$ of particles of the diameter $9-12 \mathrm{~nm}$, and $21 \%$ of the diameter $15 \mathrm{~nm}$.
\end{abstract}

\section{Adsorption experiments}

The adsorption study of NGB onto nanoparticles was carried out by batch equilibrium experiments. A known mass of adsorbent $(5.0 \mathrm{mg})$ was suspended in $25 \mathrm{~mL}$ of NGB solution of different initial concentration (2.0-30.0 mg L $\left.\mathrm{m}^{-1}\right)$ in stoppered $50 \mathrm{~mL}$ flasks and kept under isothermal conditions in a shaking water bath at $150 \mathrm{rpm}$ at the desired temperature $\left(25^{\circ} \mathrm{C}\right)$. The experiments were carried out in triplicates. 
The amount of RGB dye adsorbed to gram of nanoparticles was calculated by the following equation (1):

$$
Q_{e}=\frac{\left(C_{0}-C_{e}\right) V}{m},
$$

where $Q_{e}$ is amount of adsorbed NGB on adsorbent at the equilibrium - equilibrium adsorption capacity (mg/g-1 of MNPs), $C_{0}$ is the initial concentration of RGB in solution ( $\left.\mathrm{mg} \mathrm{L}^{-1}\right), C_{e}$ is the concentration of RGB in solution at equilibrium $\left(\mathrm{mg} \mathrm{L}^{-1}\right), m$ is the mass of used adsorbent $(\mathrm{g})$, and $V$ is the volume of used RGB solution (L).

\section{The NGB removal efficiency}

A known mass of magnetic adsorbent $(15 \mathrm{mg}, 30 \mathrm{mg}$ ) was suspended in $25 \mathrm{~mL}$ of dye solution at the initial concentration of $10.0 \mathrm{mg} \mathrm{L}^{-1}$ of NGB in stoppered $50 \mathrm{~mL}$ flasks at the desired temperature $\left(25^{\circ} \mathrm{C}\right)$ for 60 seconds.

The Naphthol green B removal efficiency $(\mathrm{R})$ in $\%$ was determined based on the decrease in the concentration of the dye before and after absorption at time $t$, and calculated using the following equation (2):

$$
R=\frac{C_{0}-C_{t}}{C_{0}} 100[\%]
$$

where $C_{0}$ and $C_{t}\left(\mathrm{mg} \mathrm{L}^{-1}\right)$ were the initial concentration and the concentration of NGB at $t$.

\section{RESULTS AND DISCUSSION}

\section{Effect of the $\mathrm{pH}$ value and the dosage of $\mathrm{Fe}_{3} \mathrm{O}_{4}$}

The behaviour of MNP adsorbent is closely related with the $\mathrm{pH}$ value of the solution, since $\mathrm{pH}$ largely affects physical properties of the adsorbent molecules, such as surface charge, ionization degree and existence species. Figure 1 shows that the sorption process is only effective when the $\mathrm{pH}$ of the dye solution drops to 3; otherwise the removal efficiency decreased to $1.4-4.9 \%$ when the $\mathrm{pH}$ of the solution was $4-9$ respectively. According to this result, further experiments were conducted at $\mathrm{pH} 3$. The removal efficiency of NGB studied under acid conditions ( $\mathrm{pH} 3$ ) increased with the dose of the used adsorbent (Figure 2).

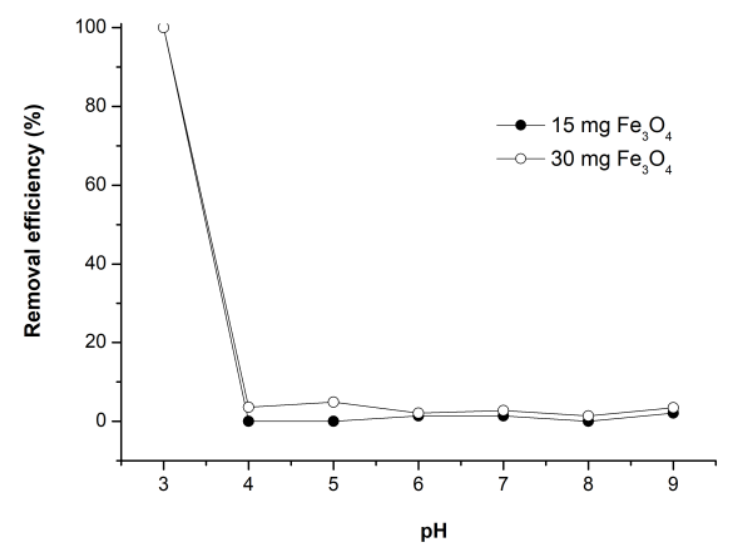

Figure 1 Effect of $p H$ value on the removal efficiency of Naphthol Green B $\left(10 \mathrm{mg} \mathrm{L}^{-1}\right)$ using magnetic adsorbent $\mathrm{Fe}_{3} \mathrm{O}_{4}$ 


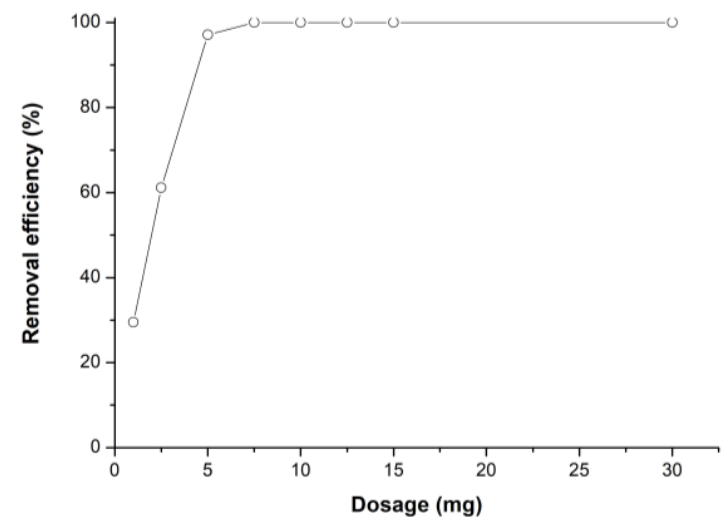

Figure 2 Effect of $\mathrm{Fe}_{3} \mathrm{O}_{4}$ dosage on the removal efficiency of Naphthol Green $\mathrm{B}\left(10 \mathrm{mg} \mathrm{L} \mathrm{L}^{-1}\right)$ at $\mathrm{pH} 3.0$

\section{The study of adsorption isotherms}

For the description of the adsorption equilibrium, the Langmuir and Freundlich isotherm equations were applied to the experimental data, both non-linear (Figure 3), while the linearized (Figure 4) forms were used to compare and calculate the isotherm parameters, which are summarized in Table 1.

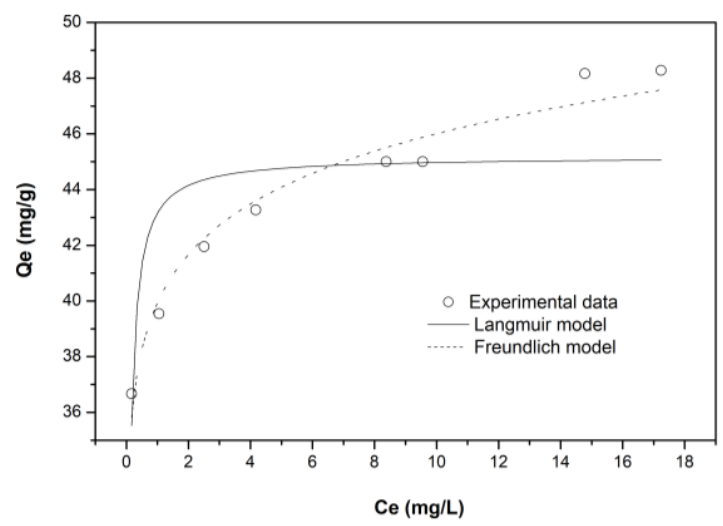

Figure 3 Adsorption isotherms of experimental data - nonlinear Langmuir and Freundlich model at $\mathrm{pH} 3,25^{\circ} \mathrm{C}, 5 \mathrm{mg}$ of $\mathrm{Fe}_{3} \mathrm{O}_{4}$

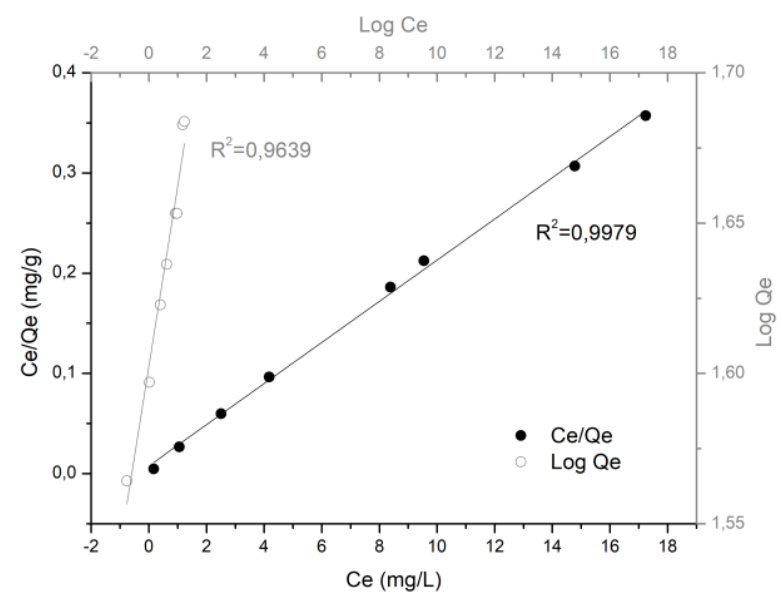

Figure 4 Adsorption isotherms, Langmuir and Freundlich linear regression at $\mathrm{pH} 3,25^{\circ} \mathrm{C}, 5 \mathrm{mg}$ of $\mathrm{Fe}_{3} \mathrm{O}_{4}$ 


\begin{tabular}{|c|c|c|c|c|c|c|}
\hline & \multicolumn{3}{|c|}{ Langmuir model } & \multicolumn{3}{|c|}{ Freundlich model } \\
\hline & $\mathrm{Q}_{\max }$ & $\mathrm{K}_{\mathrm{L}}$ & $\mathrm{R}^{2}$ & $1 / \mathrm{n}$ & $\mathbf{K}_{\mathbf{F}}$ & $\mathbf{R}^{2}$ \\
\hline & {$\left[\mathrm{mg} \mathrm{g}^{-1}\right]$} & {$\left[\mathrm{L} \mathrm{g}^{-1}\right]$} & {$[\%]$} & & {$\left[\mathrm{L} \mathrm{g}^{-1}\right]$} & {$[\%]$} \\
\hline \multirow[t]{4}{*}{ Linear } & 48.7092 & 2.64221 & 99.794 & 0.05995 & 40.0175 & 99.395 \\
\hline & \multicolumn{3}{|c|}{ Langmuir model } & \multicolumn{3}{|c|}{ Freundlich model } \\
\hline & $\mathrm{Q}_{\max }$ & $\mathrm{K}_{\mathrm{L}}$ & $\mathrm{R}^{2}$ & $\mathrm{n}$ & $\mathbf{K}_{\mathbf{F}}$ & $\mathbf{R}^{2}$ \\
\hline & {$\left[\mathrm{mg} \mathrm{g}^{-1}\right]$} & {$\left[\mathrm{L} \mathrm{g}^{-1}\right]$} & [\%] & & {$\left[\mathrm{L} \mathrm{g}^{-1}\right]$} & {$\left[\mathrm{L} \mathrm{g}^{-1}\right]$} \\
\hline Nonlinear & 45.183243 & 21.34993 & 55.941 & 16.2533 & 39.9316 & 96.158 \\
\hline
\end{tabular}

\section{Note:}

$\mathrm{Ce}$ is the dye concentration at equilibrium $\left(\mathrm{mg} \mathrm{L}^{-1}\right) ; Q e$ is the equilibrium adsorption capacity $\left(\mathrm{mg} \mathrm{g}^{-1}\right) ; K_{L}$ is the Langmuir adsorption constant $\left(\mathrm{L} \mathrm{g}^{-1}\right) ; Q_{\max }$ is the maximum adsorption capacity $\left(\mathrm{mg} \mathrm{g}^{-1}\right) ; K_{F}$ is the Freundlich constant $\left(\mathrm{L} \mathrm{g} \mathrm{g}^{-1}\right) ; n$ is the heterogeneity factor of adsorption sites (dimensionless).

According to Table 1, in the nonlinear fitting, the Freundlich model fits better than the Langmuir does. In general, the better fit of the Langmuir model demonstrated that the adsorption is implemented as the monolayer coverage on the surface of the adsorbent, while the Freundlich isotherm describes a heterogenous adsorption process that assumes an exponential distribution of active sites. The slope $(1 / n)$ in the linear model ranging between 0 and 1 is a measure of adsorption intensity or surface heterogeneity, becoming more heterogenous as its value gets closer to zero [23]. Usually, nonlinear models are more precise, than the linearised forms are. According to the nonlinear fit of experimental data, the sorption of the naphthol green B is assumed as multilayer, while the nonlinear Freundlich model fits better $(96.158 \%)$ than the Langmuir model does $(55.941 \%)$.

\section{CONCLUSION}

The main environmental problem of the textile industry is high consumption of dyes and consequently toxic pollution of water. The most critical situation is in countries known for high textile production, such as China, India, Thailand, Bangladesh, and Vietnam. The commonly known dye removal methods are not very economical or efficient. Therefore scientists are focusing on newer and more effective technologies for removing dyes from water. Nanotechnology is a relatively new technology which researchers employ for dye removal, especially the use of nanoparticles in the removal of various contaminants from the environment. Magnetic nanoparticles are low-cost, easy-to-process, reusable, and exhibit superparamagnetic properties.

The sorption process of Naphthol green B onto prepared magnetite nanoparticles is strongly $\mathrm{pH}$ dependant, while it only took place when the $\mathrm{pH}$ of the solution decreased to the $\mathrm{pH}$ value 3 . According to the isotherms modelling, the sorption is assessed as multilayer. Only $5 \mathrm{mg}$ of synthetized magnetite nanoparticles were needed for the $97 \%$ removal of the Naphthol green $\mathrm{B}\left(10 \mathrm{mg} \mathrm{L}^{-1}\right)$ from the solution at $\mathrm{pH} 3$.

\section{Acknowledgement}

The article was written with the support of the Project of KEGA Grant Agency of the Ministry of Education, Science, Research and Sport of the Slovak Republic No. 020STU-4/2021: Building an innovative teaching laboratory for practical and dynamic education of students in the field of occupational safety and health. 


\section{References}

[1] KALRA, A., GUPTA, A. 2020. Recent advances in decolourization of dyes using iron nanoparticles: A mini review. Materials Today: Proceedings, 36, 689-696, ISSN 2214-7853.

[2] GUNASUNDARI, E., SENTHIL KUMAR, P., RAJAMOHAN, N., VELLAICHAMY, P. 2020. Feasibility of naphthol green-b dye adsorption using microalgae: Thermodynamic and kinetic analysis. Desalination and Water Treatment, 192, 358-370, ISSN 1944-3986.

[3] PANDA, S. K., AGGARWAL, I., KUMAR, H., et al. 2021. Magnetite nanoparticles as sorbents for dye removal: a review. Environmental Chemistry Letters, ISNN 1610-3653.

[4] RIAHI-MADVAAR, R., TAHER, FAZELIRAD, H. 2017. Synthesis and characterization of magnetic halloysite-iron oxide nanocomposite and its application for naphthol green B removal. Applied Clay Science, 137, 101-106. ISSN 0169-1317.

[5] ALI, A. A., El-SAYED, S. R., SHAMA, S. A., MOHAMED, T. Y., AMIN, A. S. 2020. Fabrication and characterization of cerium oxide nanoparticles for the removal of naphthol green $b$ dye. Desalination Water Treatment, 204, 124-135. ISSN 19443986.

[6] NITHYA, R., THIRUNAVUKKARASU, A., SATHYA, A. B., SIVASHANKAR, R. 2021. Magnetic materials and magnetic separation of dyes from aqueous solutions: a review. Environmental Chemistry Letters. ISSN 1610-3653.

[7] ZHOU, Y., LU, J., ZHOU Y., LIU, Y. 2019. Recent advances for dyes removal using novel adsorbents: A review. Environmental Pollution, 252, 352-365, ISSN 1873-6424.

[8] BUSHRA, R., MOHAMAD, S., ALIAS, Y., JIN, Y., AHMAD, M. 2021. Current approaches and methodologies to explore the perceptive adsorption mechanism of dyes on low-cost agricultural waste: A review. Microporous Mesoporous Materials, 111040. ISSN 1387-1811.

[9] ZIARANI, G. M., MORADI, R., LASHGARI, N., KRUGER, H. G. 2018. Azo Dyes. Metal-Free Synthetic Organic Dyes, Elsevier, 2018. 47-93 p. ISBN 9780128156476.

[10] NEUGEBAUER, W., SESSA, C., STEUER, C., ALLSCHER, T., STEGE, H. 2019. Naphthol Green - a forgotten artists' pigment of the early 20th century. History, chemistry and analytical identification. Journal of Cultural Heritage, 36, 153-165. ISSN 12962074.

[11] HUNG. Y.-T., ADESANMI, BUKOLA M., PAUL, H. H. 2020. Coagulation-Flocculation Treatment for Naphthol Green Band Flour Wastewater. International Journal for Modern Trends in Science and Technology, 6 (12), 190-197. ISSN 2455-3778.

[12] CHENAB, K. K., SOHRABI, B., JAFARI, A., RAMAKRISHNA, S. 2020. Water treatment: functional nanomaterials and applications from adsorption to photodegradation. Materials Today Chemistry, 16, 100262. ISSN 24685194.

[13] AHMADI, N., CHAIBAKHSH, N., ZANJANCHI, M.A. 2016. Use of Descurainia sophia L. As a natural coagulant for the treatment of dye-containing wastewater. Environmental Progress \& Sustainable Energy, 35 (4), 996-1001. ISSN 19447442.

[14] NOURMORADI H., RAHMATI Z., JAVAHERI M., MORADNEJADI K. 2015. Effect of praestol as a coagulant-aid to improve coagulation-flocculation in dye containing wastewaters. Global Nest Journal, 18(1), 38-46.

[15] BUTLER, E.B., HUNG, Y.T., MULAMBA, O. 2017. The effects of chemical coagulants on the decolorization of dyes by electrocoagulation using response surface methodology (RSM). Applied Water Science, 7 (5), 2357-2371. ISSN 2190-5487.

[16] YUKSEL, E., GURBULAK, E., EYVAZ, M. 2012. Decolorization of a Reactive Dye Solution and Treatment of a Textile Wastewater by Electrocoagulation and Chemical Coagulation: TechnoEconomic Comparison. Environmental Progress \& Sustainable Energy, 31(4), 524-535. ISSN 19447442.

[17] LALNUNHLIMI, S., VEENAGAYATHRI, K. 2016. Decolorization of azo dyes (Direct Blue 151 and Direct Red 31) by moderately alkaliphilic bacterial consortium. Brazilian Journal of Microbiology, 47(1), 39-46, ISSN 15178382.

[18] LOU, Z., ZHOU, Z., ZHANG, W., ZHANG, X., HU, X., LIU, P.,ZHANG, H. 2015. Magnetized bentonite by $\mathrm{Fe}_{3} \mathrm{O}_{4}$ nanoparticles treated as adsorbent for methylene blue removal from aqueous solution: Synthesis, characterization, mechanism, kinetics and regeneration. Journal of the Taiwan Institute of Chemical Engineers, 49, 199-205. ISSN 18761070.

[19] DE GISI, S., LOFRANO, G., GRASSI, M., NOTARNICOLA, M. 2016. Characteristics and 
adsorption capacities of low-cost sorbents for wastewater treatment: A review. Sustainable Materials and Technologies, 9,10-40, ISSN 22149937.

[20] SIVASHANKAR, R., SATHYA, A. B., VASANTHARAJ, K., SIVASUBRAMANIAN, V.2014. Magnetic composite an environmental super adsorbent for dye sequestration - A review. Environmental Nanotechnology, Monitoring and Management, 1-2, 36-49. ISSN 22151532.

[21] DAMASCENO, B. S., DA SILVA, A. F. V., DE ARAÚJO, A. C. V. 2020. Dye adsorption onto magnetic and superparamagnetic $\mathrm{Fe}_{3} \mathrm{O}_{4}$ nanoparticles: A detailed comparative study. Journal of Environmental Chemical Engineering 8(5), 103994. ISSN 22133437.

[22] BYCHKOVA, A. V., SOROKINA, O. N., KOVARSKI, A. L., SHAPIRO, A. B., ROSENFELD, M. A. 2011.The Investigation of Polyethyleneimine Adsorption on Magnetite Nanoparticles by Spin Labels Technique. Nanoscience and Nanotechnology Letters, 3(4), 591-593.

[23] FOO, K.Y., HAMEED, B.H. 2010. Insights into the modeling of adsorption isotherm systems. Chemical Engineering Journal, 156(1), 2-10. ISSN 13858947.

\section{ORCID}

Zuzana Sanny

0000-0003-2079-4277

Alexandra Kucmanová

Kristína Gerulová
$0000-0003-3089-7712$

0000-0003-2588-8627 